\title{
Can Christians really make a difference? A response to the call for change to make the world a better place
}

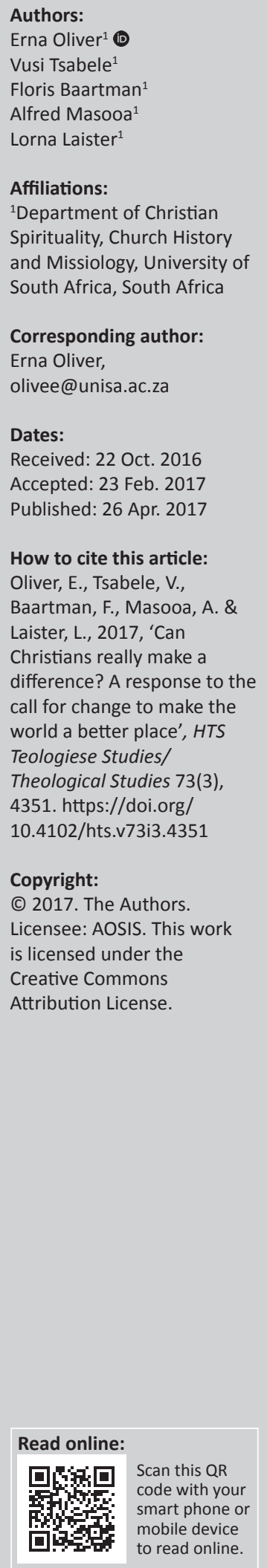

Christianity changed the world for the better through the development of education, charity organisations, art, music, law and medical care among others. However, not all changes initiated by Christianity were positive. The Christian religion was also responsible for division, death, destruction and war. Focusing on the positive changes, nearly 500 years after the reformation though, it seems as if Christianity has lost its renewing and transformative powers. It seems as if society, politics and the economy are pressurising Christianity to conform to the world and not the other way round. Therefore, the research focuses on the question whether Christians can bring about positive change and transformation to the current problems in society. What can Christians do to provide a religious response to current persistent societal problems? Change agents - people who drive positive change - are capable and competent, make use of networks, are visible and contactable and are often also outsiders in the communities they serve. Examples of the work done by change agents - Christians within their local communities - through small-scale community projects are showcased here to suggest possible ways forward for dealing with persistent problems from a Christian point of view.

\section{Introduction}

History itself is evidence of the huge impact that the actions of Christians had on bringing about change and development to society. Both individuals and society as a whole went through dramatic changes as a result of the influence of the Christian religion during the past 2000 years. The works of Schmidt (2004), Hill (2005) and Sunshine (2009) are all testimony to an overview of the changes the Western world experienced during the last two millennia as a result of the faithbased work and dedication of Christians. Although it must be confessed that not all the changes and developments that were fuelled by the Christian religion were positive, and society was also negatively impacted by the activities of Christians, the focus here will be on the need for positive change in the South African context, with its predominantly Christian population, where the celebration of the 500-year commemoration of the reformation will soon move into the spotlight in religious circles.

\section{Change as a descriptor for the Christian faith}

On the one hand, change often seemingly comes too fast for us to keep up with. It requires us to leave our comfort zones well before we feel the urge to even move a finger. This is often true in religious life where both clergy and laymen do not like to be pressed to move from traditional and well-known practices to accepting different modes of expressing our faith that are keeping up with development in society. On the other hand, change often cannot happen fast enough. Examples of this are found in a wide range of daily activities such as the need to find cures for terminal illnesses or to develop cost-effective cellular phones with even more and faster functionalities, linked with the need for better, faster and cheaper connectivity options.

Besides the tempo through which change influences our lives, it is true that change influences all aspects of our lives - from growing older every second of each day to our behavioural patterns that also change with time. Living in the technologically supported network society completely changed the way many people work. For thousands of people who were office-bound a decade or two ago, there is no need any more to be in a specific location to be able to do their daily chores. Although faith and religion are often seen as aspects of life that do not really change drastically except when one converts from one religion to the other, there are also trends and developments in these aspects of life that make it possible to apply the statement that change is constant and inevitable. Looking back at history and also when one reflects on the changes that Christians are bringing about in their communities today, it is possible to describe Christianity in one word, and 'change' could well be that word. 
The Bible, and more specifically the New Testament, provides evidence of radical changes that took place in the lives of people and society due to the preaching and ministry of Jesus Christ. The disciples and other followers of Jesus found their world views and social status drastically changed due to their convictions even during the few years of Jesus' ministry and to a much larger extend very soon after his crucifixion and ascension. Their changed attitude towards both the Jewish and Roman practices of the day, combined with their high moral standards, soon landed them into trouble with religious and political authorities (Ac 4:20; Schmidt 2004:19, 23, 27).

The Christians, as they were referred to, practised a morality that contravened common Roman practices such as abortion, infanticide, abandoning of children, suicide, homosexuality (please qualify this with reference-added at end of sentence) and the degrading of women, children and slaves to possessions (Eusebius in Schaff 1885; Schmidt 2004:27; Sunshine 2009:29,33). This and their refusal to partake in the official religious and social events of the Empire resulted in them being marginalised and also severely persecuted. Their choice not to defend themselves but rather to spread love and forgiveness through word and deed to all, regardless of race, sex, ethnicity, class or status, fuelled the growth and expansion of the young religion that soon started to transform and change the society (Schmidt 2004:65, 70, 151, 125, 199, 194, 292, 314, 345, 374; Sunshine 2009:35-54).

There were, of course, also changes within Christianity, of which the development of institutions such as monasticism, the schism between the eastern and western churches and the reformation are examples that not only determined Church History but also influenced world history to a large extent (Hill 2005:152-180). Furthermore, as already noted, change is not always positive and beneficiary to society. Religious changes are no exception (cf. Hunter 2010).

To summarise, it can be stated that during the last 2000 years, Christianity was a major role player that influenced changes to society, sometimes for the better and other times in a negative way, whereas in some instances, there were both positive and negative results from the same event. One such event was the 16th century Reformation, of which Christians all over the world will celebrate the half millennium anniversary in 2017. The bloodshed, wars and schism that resulted from the Reformation (cf. MacCulloch 2005) will be remembered together with the translation of the Word of God into hundreds of languages and dialects and the spreading of the Good News all over the world. Christians must be cautious not to focus too much on the glories of the past, though. Although we should recall the achievements of the past that were done within specific circumstances, the current celebrations should also focus on how the present challenges and future opportunities can be addressed and on what Christians can do to bring about positive change and hope in unstable and hostile social environments. Being reminded of the achievements by Christians of previous generations, should encourage believers not to become victims but instead to use their strength and faith to be active agents of hope and change. The main questions should be: How can Christians really make a difference? How can we respond to the call for positive and constructive change? When asked, 'What is your dream?' during an interview with Beliefnet: Inspire your day, Dr Rick Warren (2005) answered with these powerful words:

I'm looking for a second reformation. The first reformation of the church 500 years ago was about beliefs. This one is going to be about behaviour. The first one was about creeds. This one is going to be about deeds. It is not going to be about what does the church believe, but about what is the church doing.

Nearer to home, Archbishop Desmond Tutu, in his address at a conference on 'The Reformed Churches in South Africa and the struggle for justice: remembering 1960-1990' held at Stellenbosch University in May 2012, said that we as South Africans are in desperate need of a transformation from words to deeds. In anticipation of the anniversary celebrations of the reformation, it is clear that Christianity is again due for a major makeover. It is not enough just to remember and celebrate the great and positive achievements and changes that Christians brought about in the past. It is necessary for Christians today to act and be and bring about the change that society needs.

\section{South Africa needs positive change}

Christians living in South Africa are currently experiencing a need for renewal in their daily lives after 22 years into democracy. More than $80 \%$ of the country's population claims to be Christians (Statistics South Africa 2004). However, when one evaluates living conditions in our country, there is not much to be seen of a high moral Christian lifestyle and the positive, caring and forgiving attitude that is supposed to accompany a society claiming to live through Christ.

Although there seems to be a slight improvement on some country listings and indexes since 2011, it could also be due to deteriorating circumstances in other countries rather than improvements in the South African situation. In 2011, our country was number 123, which is tagged 'medium low' on the Human Development Report of the United Nations (United Nations Development Programme [UNDP] 2011), but improved to 'medium' at number 116 in 2014. During 2011, South Africa was number 128 - low and declining - on the environmental development index (Yale \& Colombia Universities 2012), but improved dramatically to number 81 on the same index of 2016 (Yale 2016).

The Global Homicide Book (2014:33) showed a significant decrease in homicide in South Africa between 1996 and 2011, from 64.9 to 30 per 100000 of the population. The female homicide rate is, however, still five times above the average global rate (Global Homicide Book 2014:54). In 2012, South Africa was one of the top 10 countries on the world index for murder and the total number of crimes committed (United Nations Office on Drugs and Crime [UNODC] 2012). During 2015 and 2016, South Africa stayed in the ninth position 
on this list (ABCnewspoint 2015; Themeshnews 2016). South Africa is also listed as one of the 10 most dangerous countries in the world (Alltoptens 2014; Hardy 2012).

The number of recorded road deaths proportional to the country's population was until recently close to the highest in the world (Scherer 2013). By 2014, however, our country did not make the top 10 in this list, although the index is still very high (World Health Rankings 2014).

South Africa has the highest number of people living with HIV in the world (KFF 2012:1). In 2014, it was estimated that a staggering $12 \%$ of the population is HIV positive (CIA 2014).

The government is seemingly unable to adequately address the increasing unemployment issue (Roelf 2016), whereas the economy is drastically slipping backwards with South Africa currently only the third largest economy in Africa (Viljoen 2016). 'Like in the 1980s, the poor are still angry and the government is still out of touch' (Makhanya 2012).

Looking at this scenario, it is clear that South Africa is in need of positive change on most levels of society. It is also clear that the government is not winning in the struggle against economic backsliding which, to a large extent, is feeding the deterioration at all other levels. Capitalising on the fact that South Africans, at least in theory, are a Christian nation, the government, a few years ago, admitted to its inability to promote positive social transformation (Jackson 2007) and requested religious institutions to provide the infrastructure to encourage and cultivate positive social change. However, despite the voices of people like Archbishop Tutu and Allan Boesak, it seems as if the Christian churches are also unable to promote large-scale positive change. It seems as if the churches are unwilling to commit to active transformation activities. Even more worrying than their lack of actions is the silence (cf. Camp 1994). There are no outcries or statements and calls for action by church leaders frequenting the news and social media platforms.

When asked why the churches do not seem to have a positive influence on the population, it could be argued that these institutions are too accommodating in their efforts to sustain themselves towards economic survival in the 21st century. Afraid to step on toes or to be labelled as fundamentalists and scared of isolation or confrontation, or even getting on the wrong side of government, business and social networks, most of the churches choose to be compliant, silent and inactive in the public sphere. The lives of church members are neatly divided into individual compartments where religion is a private affair that does not meet or mix with work or social life, whereas culture (socially constructed by so-called in and out lists and groups) is constructing the rules by which people abide. Faith no longer determines choices of lifestyle, career or day-to-day actions. And following the silence of the institutions, individuals refrain from speaking, advocating and acting their convictions in public.
In order for positive social change and transformation to become a reality in South Africa, one must agree with the statement made by Astin and Astin (2000:iv) that positive social change can only happen when individuals take it upon themselves to speak up and get involved in social problem areas by making a difference through their own actions, hard work, dedication and commitment, despite resistance and having to persist against all odds. People acting in such a way are called change agents. A change agent is a person whose presence and thought processes cause an alteration from the traditional or conventional way of handling a problem or thinking about a controversial issue (Oliver 2013). Both the current situation in South Africa and the larger picture of the commemoration of the impact that the reformation had on the lives of people worldwide made it clear that there is an acute shortage of people to fill the ever-increasing job opportunities in the change agency market. There is a need for adequately equipped, passionate people who are willing and able to take up the challenges of this voluntary and rewarding work, knowing that although they sacrifice time and effort and often also money, they would probably not personally gain from their input in any way except the satisfaction of helping others and contributing to making the world a better place to live and work in. South African Christians (no matter where in the world they are - some of the South African-born change agents are living abroad) should, based on the convictions of their faith, be able to act as positive agents of change, giving renewed life to the words of Pliny the Elder who proclaimed about 77AD that 'there is always something new coming out of Africa' (Gaius Plinius Secundus 1939).

It is necessary to briefly dwell on the aspect of change theory and how it was applied before explaining the Change Agent Project in more detail. There are a number of scholars who provide useful theories on change, including Lippitt, Watson and Wesley (1958), Rogers (1962), Havelock (1973), Weiss (1995) and Kotter (1996). For this project, the Planned Approach to Change by Lewin (1947a) is implemented.

\section{Change theory}

Kurt Lewin can be seen as the father of contemporary theories of change (Schein 1988:239). Although his work has been criticised (as discussed and evaluated by Burnes 2004:992995), his focus on behavioural change on the bases of four interlinking concepts was successfully implemented to bring about effective change through the Change Agent Project of Theology at the University of South Africa. We hope that this project could use this theoretical foundation to expand and bring about even further sustainable positive change to the South African society.

Lewin's Planned Approach to Change is based on the complex interaction of four concepts: Field Theory, Group Dynamics, Action Research and the 3-Step Model to Change. These aspects are linked to each other through the theme of the group to which a person belongs, because this 
group (in our case, South African Christians) forms the basis for the person's perceptions, emotions and actions (Allport 1948:vii).

Field Theory, in an attempt to understand group behaviour, is mapping out the field in which this behaviour takes place, observing the current situation as it is preserved by certain conditions, beliefs and circumstances (Lewin 1943:172). Students were asked to identify ecumenical problem areas within their (work, faith or living) communities and to state their views on why these are persistent problems.

Although Lewin (1947b) argues that it is fruitless to concentrate on changing individual behavioural patterns, it is important to acknowledge that groups need leaders and visionaries to initiate the process of change and to sow the seeds of cognitive dissonance ${ }^{1}$ (Festinger 1957; Travis \& Aronson 2007) that motivate members of a group to join in the movement towards change. Students of Theology were encouraged to not only think about the problems they identified and speak up in their communities to make others aware of the same but also be aware that change is possible and problems can be addressed in a constructive and positive way.

Examples of the positive influences Christians had on society through the ages are used to motivate and stimulate positive and critical thinking processes in aid of moving towards the next step which is action research. Counting on the 'great amount of good-will, or readiness to face the problem squarely and really do something about it' (Lewin 1946:201), students are encouraged to act. The first step is to select a group (youth, council, congregation, residents or colleagues) where the problem can be confirmed, discussed and where possible solutions could be researched and tabled. The sustainability of such solutions is important and this is where the 3-Step Model to Change is implemented.

First of all, people need to be made aware of the problem, the need for change and the possible solutions (through the process of unfreezing - Lewin 1947a). Sometimes, encouraging people to leave their comfort zones and to assist positive change needs an emotional or religious grounding (Lewin 1947a:229). There should be careful planning (action plans) to choose the most effective and appropriate actions to promote positive, sustainable change. Evaluation of the process and outcomes must be done in order to ensure that the lessons learned are implemented and the successes developed into sustainable changes (in the refreezing stage). Students are encouraged to work within teams and groups, to investigate a wide range of possible solutions to the identified problem and to make use of action plans (with fixed timelines, tasks assignments, feedback procedures and extensive lists) as well as to facilitate evaluation sessions. These evaluation sessions should focus on both failures and successes. Lessons learned and debriefing are as important as celebrating success and planning sustainability.

1.Cognitive dissonance is a tension often experienced by people when they discove that their behaviour, emotions and beliefs are not in harmony.
Lewin was concerned with resolving social conflict through behavioural change (cf. Burnes 2004:986), and his theory provided a fruitful grounding for a project aimed at promoting positive change in the South African society through smallscale projects initiated by second-year Theology students who study through the University of South Africa.

\section{The Unisa Change Agent Project}

Unisa is an open distance education university in South Africa serving more than 400000 students from 130 countries. The institution, both through its staff and large number of students, could potentially have a huge influence on society. Oyler (2012:1) says that the curriculum of a higher education institution should be the place where students can encounter the world, its histories and its people and analyse current trends. Students must also be encouraged to become responsible and active citizens (Oyler 2012:8) with sound moral visions (Oyler 2012:70), who are actively involved in upliftment projects. Higher education should empower citizens (Johnston et al. 2011:98) to reflect critically on their place in society and to practise skills and abilities that underlie good citizenship (UNESCO 1997:24).

In the light of the need for positive change in the South African context as referred to above, the staff members in the Department of Christian Spirituality, Church History and Missiology in the cluster of Theology at Unisa are aiming to promote positive change through the lives of both its staff members and graduates. Modules and courses enhance positive values such as the commitment to liberation, justice, reconciliation and care for the environment. The courses are structured to include and focus on these issues, because an academic qualification should be more than a certificate showing that the student gained sufficient academic knowledge. Degrees should also convey the graduate's competency and skills to use this knowledge to the advantage of other people and to initiate positive change as community leaders and creative thinkers. In Theology, this is not negotiable. One of the huge advantages of teaching Theology through distance education is that it provides opportunities to bring positive change to isolated and remote communities.

One of the key performance areas (KPA) that Unisa (2013) staff members need to participate in is community engagement. Community engagement is defined as the:

scholarly activity of academic research and teaching that involves external communities and stakeholders in collaborative activities that address the socioeconomic imperatives of South Africa and the African continent while also enriching the teaching, learning and research objectives of the university. (p. 3)

The community engagement actions of staff members should ideally also link to both their teaching and learning activities on the one hand as well as their research on the other hand. Both these activities are also listed in the staff KPAs. Being a lecturer in the cluster of Theology, linking my teaching role of the academic formation of spiritual leaders with actively making a difference for the betterment 
of lives of people outside the academic sphere, is not as obvious as it would seem to be. While reflecting on how to improve the quality and impact of a second-year course named 'World Christianity and Ecumenism', it became clear that there are ample opportunities to expand the impact of the course outcomes into the lives of the students and the communities they live and work in. Both the content and the project-type assessment methods used in the course allow for interaction with the students in such a way that they could be asked to do and report on a project that would focus on change agency in their congregations and communities. Most of the students are Christians equipping themselves to become pastors or other spiritual leaders. These people should be able to reach out to and facilitate change for the poor, the marginalised, the victimised and the isolated in their faith communities. It is the small acts of kindness and care that can make a big difference and provide hope to those in need. The short time frame of 4 weeks sets in the assessment plan of this module to plan and institute some kind of transformation in society, and makes it an ideal small project to enhance positive change.

The description of the assessment task in the course content refers to the meaning of words such as 'reformation', which has a Latin root and could mean 'to clean from corruption and inefficiency, or to perform any seemingly impossible task' (The Free Dictionary), and 'transformation' which means 'a marked change in appearance or character, usually for the better' (The Free Dictionary). The task emphasises that each person can be an agent of change and that each Christian should be an agent of positive change. This process should start with personal enquiry. Students are asked to answer questions such as: What is your dream? Are you fulfilling your dream by enrolling for this module? What do you want to change in yourself to be a Christian living according to your convictions? What do you want to change in your (faith) community? What will you need to be able to do this? The students are encouraged to work towards fulfilling their personal dreams and then to look further - to their families, schools, work places and environment. They also need to look at their congregations, their denominations and the ecumenical issues that are of interest to their faith communities. The students need to identify current problems that they, together with members of their faith communities and ecumenical partners, can address and, if possible, start to solve by working together and creating ecumenical cooperation opportunities. The students are encouraged to identify what they can do to initiate the change they want to see and experience in the community. They need to share their dreams with others and work on a blueprint for change. In some cases, the dream needs to be broken down into small and manageable pieces for them to be able to set the action plan for change in motion. Not much can practically be done in only 4 weeks, but most of the students choose to give the project a longer lifespan than just the period that they need to report on for assessment purposes. This is clear from the voluntary feedback received using a routine questionnaire that is sent to the students 6 months after completing the course. The final part of the project requires students to showcase their projects, including both their successes and the failures (students are not penalised for failures and are encouraged to see failure as an opportunity to learn and adjust in order to succeed in successive projects and actions). The students report on their projects that were aimed at positive change: why it was done, where it happened, what they did and what the results were.

What follows below are a few short examples of such projects that students recently did. One of these projects took place in rural Mpumalanga, two others in urban areas of KwaZulu-Natal and Cape Town. One of the projects was conducted in Germany. These examples show links to the meaning of the words 'reformation' and 'transformation' as portrait in the course material. These initiatives could act as seeds for a new reformation by succeeding with a seemingly impossible task and creating positive transformation through small but important projects that achieve a marked change for the better in the lives and living conditions of societies through the intervention by dedicated Christian change agents.

\section{Our actions today affect our children tomorrow}

\section{Vusi Tshabele: The problem: Rhino poaching}

I am living close to the Kruger National Park in the eastern part of South Africa. In this community, between 300 and 400 people are employed by SANParks, and there are also a number of people employed by the private game reserves adjacent to the Kruger National Park. None of these people earn good salaries, although the work that they do is dangerous and stressful. These people are supposed to protect endangered animals like rhinos from poachers but too often they, who are supposed to protect these helpless animals, are the ones that either help the poachers or become poachers themselves in order to make some money (Pijoos 2016). It is sad but true that our own brothers and sisters from our own community are the ones that endanger the lives of other game rangers and the endangered animals. More than 1100 rhinos are already killed in the Kruger National Park. This means that when our children visit the park, they are not likely to see any rhinos due to the diminished numbers. The park management brought some measures in to counter this that involved armed response, but even the threat of being killed does not scare some of these poachers. This means that some of these people working in the park and those who were poachers or became poachers have lost their lives. More than 300 people, mainly from neighbouring countries, and about 30 South Africans have been killed in the struggle to protect the few remaining rhinos. The children of those who are killed now often hate the people working in the park because they see them as the killers of their fathers. They do not understand the significance or the importance of nature conservation at all (see Figure 1). 


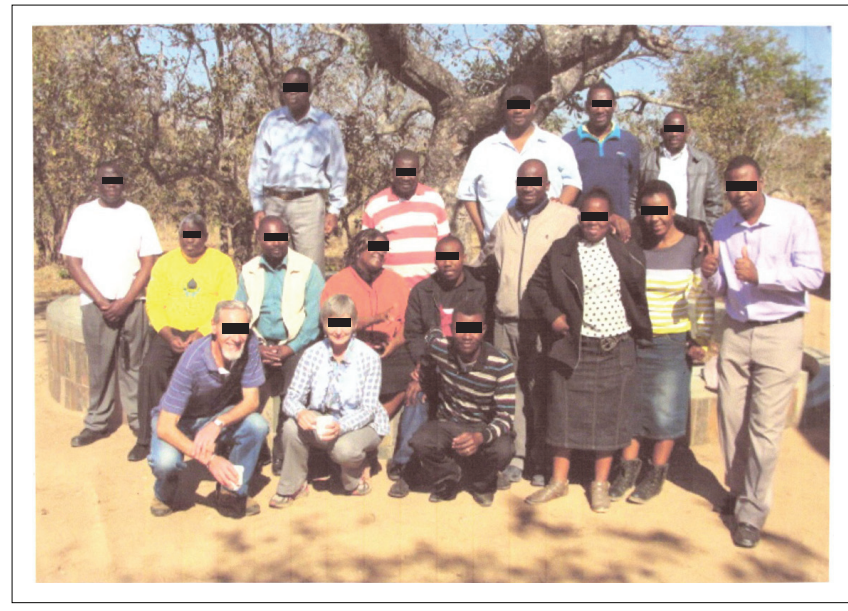

Source: Photo provided by Vusi Tshabele

FIGURE 1: The anti-poaching rhinos in Africa group. Vusi Tshabele stands on the far right of the front row.

\section{The project: The faith community and nature conservation}

For the Change Agent Project, I focused on our responsibility to take care of God's creation. I attended the 3-day Conservation Leadership Group training at the Wildlife College in the Timbavati (Environmental working Team of Timbavati College) to gain knowledge and skills needed to promote nature conservation. The aim of this course is to increase environmental awareness and responsibility in previously disadvantaged communities and to capacitate potential conservationists into future leaders in conservation who can initiate positive change.

The pastors from the different denominations gathered to unite as the body of Christ. This abolished division and motivated us to be one in service. We, the pastors, are the ones that must educate the Sunday school teachers and the elders of the community on the issue of nature conservation. The community faith members (Thulamahashe) are the ones that could inform and inspire the youth to love and respect nature and to conserve what God has given us for the coming generations.

I presented a sermon on this, based on Psalm 8:1-8. The responsibility of the faith community focuses on three aspects, namely God and the creation, myself and the creation and life in general and the creation.

God guides and manages his creation in love; through love, man must do the same. God put man on earth to care for and watch over it, to use its resources wisely and to protect it for future generations. I am part of the creation of God, and I need to care for and acknowledge that God also created everything else.

The faith community must be inspired to see creation and nature with new eyes, not as an attraction for rich people but as a gift from God that we need to care for and protect for future generations. This is the message that we, the pastors of the community living next to the Park, must teach to our congregants. Our faith should be part of our world view and actions. Religion, and not only economy and politics, must form a major part of my work ethic, actions and decisions. The pastors must also speak about nature conservation as a career opportunity for our youth.

We are part and parcel of the nature or creation moulded and supported by the hand of God. Without nature, man cannot survive, and we as humans must take responsibility to care for our environment. This is the message to our faith community living next to the Kruger National Park.

\section{Cleaning up our neighbourhood in Mitchells Plain Floorsie Baartman}

The photos below shows what was done during and after the cleaning operations took place. The City Council put up a NO ILLEGAL DUMPING sign. Furthermore, for the sake of safety, they also enclosed the electrical mini substation with a metal box.

We are appointed by God to be ambassadors for all on earth. In the street where I live, there is an Anglican Church, a United Church, a Presbyterian Church and a Charismatic Church. In total contrast to the lovely church buildings, I observed the following solid waste on the open spaces and fields around my home: packaging materials, food, plastic bags, nappies, furniture, paper, tyres and building material (see Figures 2-4). This contrast calls us to revisit our Christian value system in the light of the current ecological crisis.

After a brainstorming session on the problem, the members of our church and people from the immediate area decided to contact the church leaders of the area to ask for volunteers to help with the clean-up operation. The Men Ministry, Women Ministry, the Youth Ministry and the Sunday school were involved to ensure that people from all ages are involved. The city council was also contacted to assist with the huge task. Finally, flyers were distributed to inform and educate the members of the community about waste management.

The project involved several volunteers from the different churches and the immediate community. Although this was a new experience for most of the volunteers, the cooperation of experienced workers from the city council ensured a smooth process and guaranteed our success. In the end, the project was relatively easy and our neighbourhood was clean, while the inhabitants learned valuable lessons about waste management. We are the stewards of the earth, and it is our obligation to conserve its resources and productivity for the coming generations. 

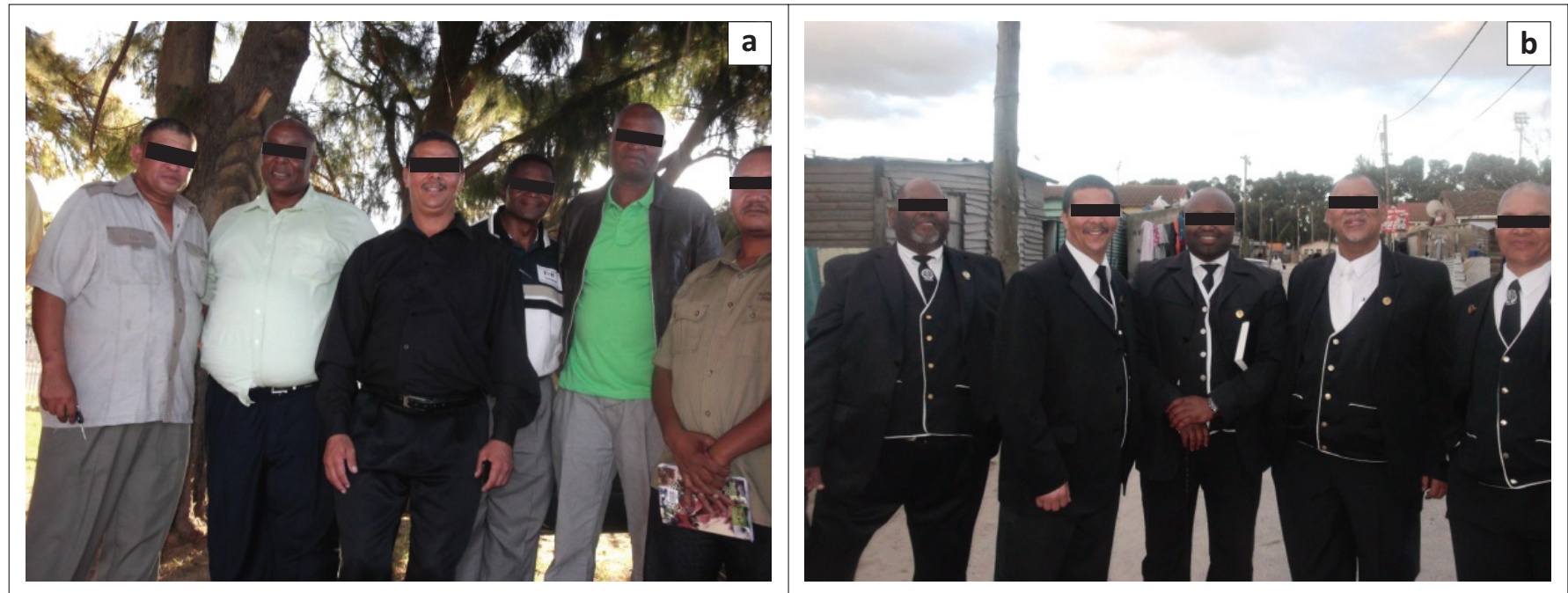

Source: Photos provided by Floris Baartman

FIGURE 2: (a) Floorsie Baartman (third from left) is pictured with volunteers from the city council and congregations who participated in the cleaning project to provide a clean and healthy environment for the community of Mitchells Plain in Cape Town. (b) Floorsie Baartman (second from Left) is pictured together with some members of the church council.
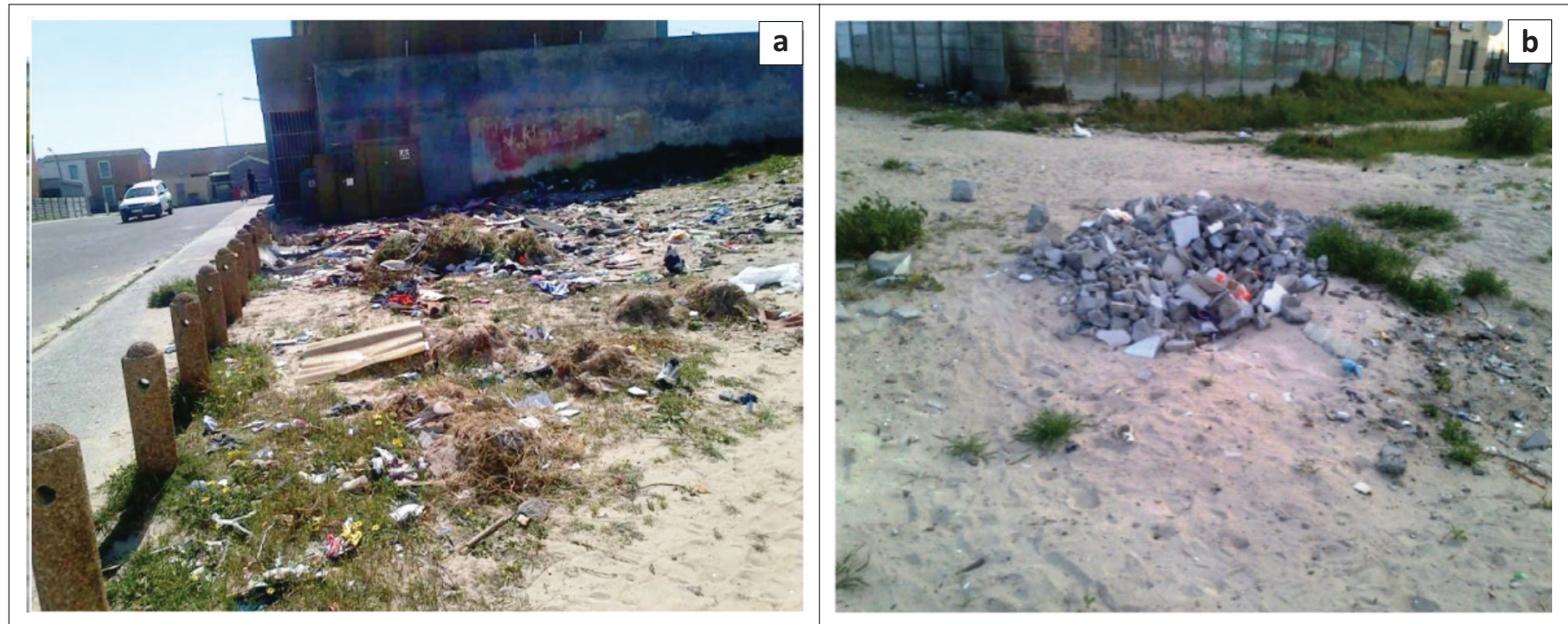

Source: Photos provided by Floris Baartman

FIGURE 3: The photos above were taken before the project started, showing household garbage and building rubble dumped on AZ Becman Street in Mitchells Plain, Cape Town. The arrow in the left upper corner indicates the house where the Baardman family stays.

\section{Ubuntu in Germany Alfred Masooa}

Richtsberg is a suburb of the university town of Marburg in Germany. It is where I reside. Most of the people living in Richtsberg were not born here. They moved here to study or work, and there are also a large number of people who come from outside Germany. Some are from Asia or Africa and others from Eastern and Southern Europe. When one walks in the neighbourhood, there is a sense of isolation and individualism. Even a friendly greeting is frowned upon. The aim of this project was clear: To initiate 'ubuntu' (a Xhosa/ Zulu ideology focusing on people's allegiances and relationships with each other, humaneness and commonality) into the individualistic, instant life, technology prägt (a German word meaning to be characterised) and consumerist gesellschaft (German word referring to a hypothetical mode of society, made up of self-serving individuals linked by impersonal ties) by offering a free voluntary service to the community. Volunteers would assist the members of the community with whatever they need help with, ranging from walking their dogs to dusting furniture, watering plants during holidays, cleaning the basement of bulky waste-like old furniture (called Spermüll), painting walls, rearranging furniture, cutting lawn or just spending time together enjoying coffee and cake.

Since I was already involved in this project, aiming to meet the same ecumenical vision as the Change Agent Project, I decided to report on this experience. The project is based on Romans 8:19-20:

The creation waits eagerly, longing for the revealing of the sons of God. For the creation was subjected to futility, not willingly, but because of him who subjected it, in hope. 

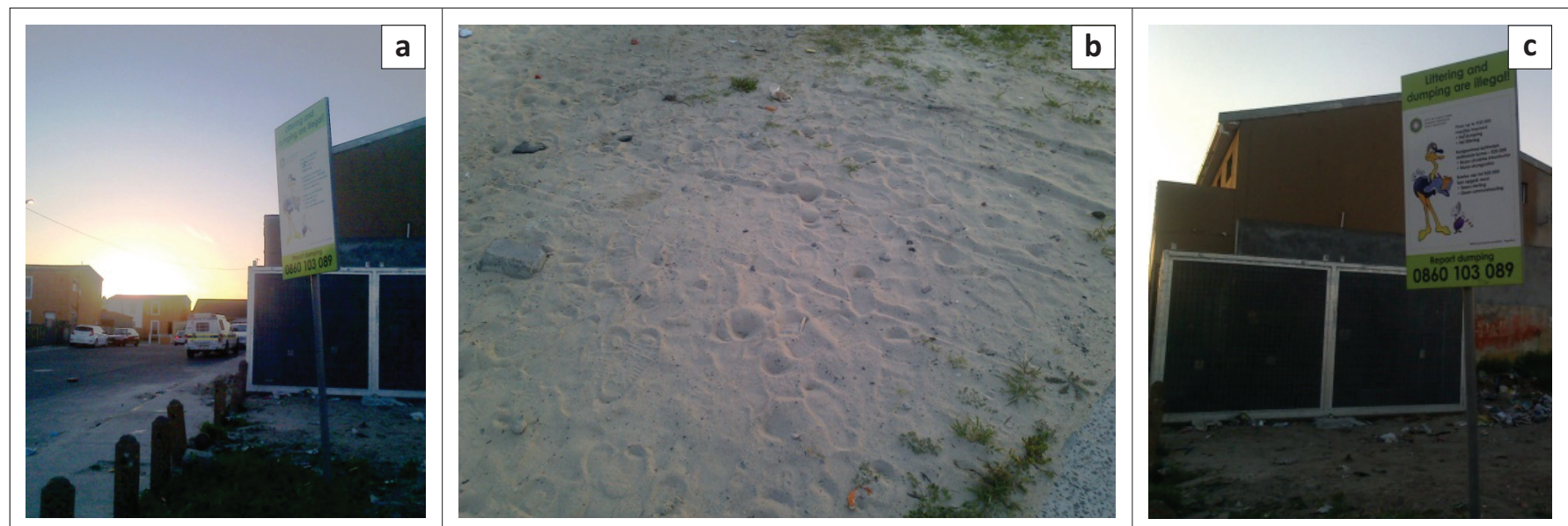

Source: Photos provided by Floris Baartman

FIGURE 4: ( $a$ and $b$ ) The photos were taken before the project started, showing household garbage and building rubble dumped on AZ Becman street in Mitchells Plain, Cape Town. The arrow in the left upper corner indicates the house where the Baardman family stays. The photos below shows what was done during and after the cleaning operations took place. (c) The City Council put up a NO ILLEGAL DUMPING sign. Furthermore, for the sake of safety, they also enclosed the electrical mini substation with a metal box.

We wanted to create room for the next wave of social interaction, but we also wanted to have well-known place as central reference point for the initiative. Thus, we partnered with the Christus-Treff Marburg Church Missionary Service, known as 'CenTraL', that is already active in the community. We wanted to show both the volunteers and the community that help is not only available from organised professionals and that this kind of support is not once off but will be available for the longest possible period. Each volunteer was asked to commit his or her service and time on a long-term basis. This means that the initiative was a once-off organised event, yet aimed at building lasting relationships.

After brainstorming, the members of the organising team were linked to their tasks. The organisers meet with the volunteers and individuals who help identifying the needs of the community. As a result of these meetings, we decided to offer a free coffee and cake station for both the volunteers and the members of the community, and a hairstylist offered her service for free to the aged in the community.

A total of 57 volunteers made up an impressive network of specialists. They included social workers, construction workers, pastors, teachers, managers, garden architects, medical professionals, electro-mechanics, a carpenter, students in various fields and young people in various internships.

The community responded with a large array of tasks for the volunteers to do on the project day: cleaning floors, removing bulky stuff from garages and basements, moving of furniture for people who just moved in, dusting, walking dogs or chilling and a chat. Some people needed professional interventions and referrals were made to provide for this (Most of the volunteers used Facebook or WhatsApp for updating, sharing and effective communication). Some people required visits on a regular basis, whereas others needed strong young men to help with painting and lifting heavy furniture. Gardening at CenTraL was also one of the focus points and qualified gardeners offered their services and a free workshop on gardening. The playgrounds needed attention, and littering along the forest pathway had to be cleaned.

The project day began with a celebration service, the formation of teams and the reading of the message: 'Each of you should use whatever gift you have received to serve others, as faithful stewards of God's grace in its various forms' (1 Pt 4:10 NIV). A prayer was said, but on this day, there was no preaching or praise and worship. At the heart of this days' action was to turn our sermons and education into action and service.

A German social worker student and I were assigned to the house of an elderly man who lost his wife in 2012 after a long battle with cancer. We were supposed to clean the house but everything was clean and we ended up cleaning those places where the old man could not reach. It was clear that the man needed someone to talk to. Before we started work, we had tea and afterwards, when we asked how we could help him, he said that it would be nice if we could sit down and talk to him. He even offered to help me learn to speak German properly as my German was still under construction. We spent $2 \mathrm{~h}$ talking about all kinds of things. He invited me to visit him every week. Since that day I have a German tutor, and he has someone who dusts his house for him, and we sit and talk while drinking coffee. He also visits my family.

The project was not without problems though. After attending to their tasks, the volunteers went home leaving no one to help with gathering and storing the gardening tools and cleaning the kitchen and the coffee station. Only a few people had to do this, and therefore, it took a long time for them to get the tasks done.

Overall, the project was a success. The entire team of people made up of individuals possessing different skills and gifts, 
and the willingness to serve others in the long term made a positive impact on the community.

\section{A garden of colour and joy Lorna Laister}

I chose to do my project at the local school where our church meets for services every week. We have a very good symbiotic relationship with the school as we share the love of God together.

My project started with the need for a clean-up project. The area directly in front of the classrooms was often littered with papers and packets. It would be a project involving children and teachers - drawing us together as God's children, in order to glorify God by caring for our little part of the world.

So initially, the two main objectives were to:

1. Clean up and maintain cleanliness of the area in front of the classrooms. Advertise or inform by posters the need to look after our world.

2. Bring glory to God by caring for the garden which displays his creation.

However, I had to revise my project because when I arrived to set these objectives into action, the whole area in front of the school was super clean and tidy! It is not the children who caused the mess. The wind or vagrants could be the culprits.

So, instead of talking to the children about cleaning up, I discussed creation and God's gift to us in the form of a garden. As God asked Adam and Eve to 'dress and keep' the Garden of Eden, so must we look after creation. The garden at the front of the school has been trampled by little feet and we needed to dig it up and make it pretty again.

There are three small areas that we could beautify and three Grade 1 classes. I spoke to the caretakers and they were happy to loosen the soil for us to put compost down in preparation for planting of flowers.

I spoke to the children about the fact that God is so generous that he gives us flowers that give us pleasure. They are beautiful to look at and we can enjoy them.

So, the project continued in a slightly different form. The classes made posters and exhibited them in front of their classrooms for all to see. Instead of 'Let's keep our school clean' they chose to write something about looking after God's creation.

I bought all the plants and took enough equipment for six children at a time to plant the flowers.

First of all, they showed me their artwork. The pictures were a splash of glorious colours on the brown walls of the classrooms. All the children took part in this activity. I told them how grateful I was that they had shared the project with me. Each child who was available was able to plant a flower. Most of the children did not know what to do and some found it difficult to follow instructions due to the language barrier. The few, who were able, could show their peers and we managed to put down the compost, fill the watering cans and got to work.

At times, it was chaotic but we really did have a lot of fun! My friends from church who come to the school for 'Mothers who care' (A prayer group - we pray every week for the school, the children and council) arrived, and they helped me to keep the area clean and tidy. They were also able to explain the process in Zulu, which helped a lot.

I went to each classroom to thank the children for their support and participation. It was a wonderful way to get to know the teachers better and work alongside them. They were fantastic with the artwork and allowing the children out of class for planting the flowers. The biggest challenge to sustain this project was getting a good barrier or fence around the garden to prevent the children from playing in these areas.

I reviewed the project in June 2016. Since the project started a year ago, the gardens are tidy and still full of flowers even though some of the flowers died. The gardens are so well established now that the need for a fence became obsolete (see Figure 5).

\section{Conclusion}

The question asked is 'Can Christians really make a difference?' This short chapter responds to this question by showing how some Christians today are responding to the call for change to make the world a better place. Bonhoeffer (n.d.) once said that the life and actions of a Christian should make non-believers question their disbelief in God. When confronted with the amazing results Christians are achieving when they set themselves the task to be the creator of positive change in their communities, one cannot help but compare them with the great spiritual leaders of the past 2000 years who were the pioneers to initiate radical positive change through their faith, prayers, persistence, hard work, unwillingness to accept that things cannot change, or that they do not have the power to change them. May the work and words of these Christians be an inspiration to others to become agents of change in their communities, because this is how positive changes can happen. This is how the negatives in South Africa and the world can be turned around towards becoming positives. The movement of turning words into deeds could bring a tsunami of positive change, a new reformation (achieving the seemingly impossible) and transformation (a marked change for the better) to Christianity and to the world. 

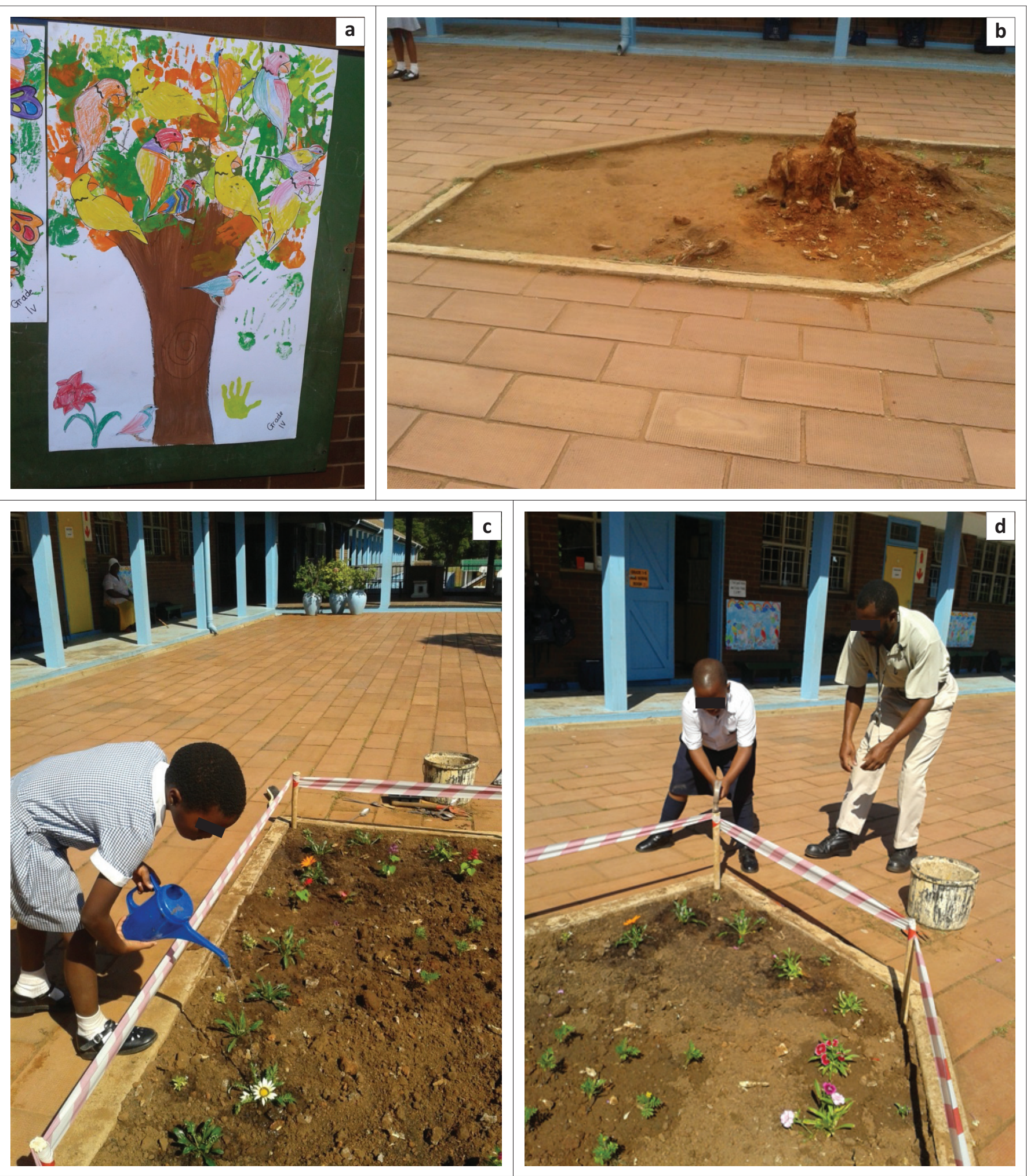

Source: Photos provided by Lorna Laister

FIGURE 5: (a) The picture created by the learners on how they would like the schoolyard to look. (b)This is one of the gardens before the start of the project (c) and (d) the children are taking care of the gardens themselves.

\section{Acknowledgements}

\section{Competing interests}

The authors declare that they have no financial or personal relationships which may have inappropriately influenced them in writing this article.

\section{Authors' contributions}

E.O. was the project leader. V.T., F.B., A.M. and L.L. were students who participated in the Change Agents Project that is linked to the second year course on World Christianity and Ecumenism. They contributed short summaries of their projects to emphasis the contribution that Christians can make to better the world. 


\section{References}

Allport, G.W., 1948, 'Foreword', in G.W. Lewin (ed.), Resolving social conflict, pp. vii-xiv, Harper \& Row, London.

Alltoptens, 2014, The top ten most dangerous countries in the world 2014, viewed 16 June 2016, from http://alltoptens.com/top-ten-dangerous-countries-2014/

ABCnewspoint, 2015, Top 10 countries with the highest murder rate in the world, viewed 06 April 2015, from http://www.abcnewspoint.com/top-10-countrieswith-highest-murder-rate-in-the-world-2015/

Astin, A.W. \& Astin, H.S. (eds.), 2000, Leadership reconsidered: Engaging higher education in social change, W.K. Kellogg Foundation, Battle Creek, MI.

Bonhoeffer, D., n.d., Quotes, viewed 13 May 2016, from http://www.azquotes.com/ author/1638-Dietrich_Bonhoeffer

Burnes, B., 2004, 'Kurt Lewin and the planned approach to change: A re-appraisal', Journal of Management Studies 41(6), 977-1002. https://doi.org/10.1111/j.1467 6486.2004.00463.x

Camp, S.T., 1994, 'Why have you been silent? The church and the abortion ban in South Africa', Columbia Journal of Gender and Law 4(2), 143-172.

CIA, 2014, The world factbook, viewed 13 May 2016, from https://www.cia.gov/ library/publications/the-world-factbook/rankorder/rankorder-guide.html

Gaius Plinius Secundus (Pliny the elder), 1939, Naturalis historia, transl. H. Rackham, Loeb Classical Library, Natural History, Harvard University Press, Pliny.

Global Homicide Book, 2014, viewed 13 May 2016, from http://www.unodc.org/ documents/gsh/pdfs/2014_GLOBAL_HOMICIDE_BOOK_web.pdf

Festinger, L., 1957, A theory of cognitive dissonance, Stanford University Press, Stanford.

Hardy, M., 2012, Top ten most dangerous countries in 2012, GetTopTens.com, viewed 14 April 2012, from http://gettoptens.com/top-10-most-dangerous-countries-in2012/

Havelock, R.G., 1973, The change agent's guide to innovation, Sage, New York.

Hill, J., 2005, What has Christianity ever done for us? How it shaped the modern world, Intervarsity Press, Downers Grove, IL.

Hunter, J.D., 2010, To change the world. The irony, tragedy, \& possibility of Christianity in the late modern world, Oxford University Press, Oxford.

Jackson, N., 2007, 'Staat gee geld vir armes in pakt met godsdiensgroepe', Beeld, 25 July, bl. 4

Johnston, B., Mitchell, R., Myles, F. \& Ford, P., 2011, Developing student criticality in higher education: Undergraduate learning in the arts and social sciences, Continuum, London.

KFF, 2012, The global HIV/AIDS epidemic, viewed 29 January 2012, from http://kff.org/ hivaids/upload/3030-17.pdf

Kotter, J.P., 1996, Leading change, Harvard Business School Press, Boston

Lewin, K., 1943, 'Psychological ecology', in D. Cartwright (ed.), Field theory in social sciences, pp. 289-300, Social Sciences Paperbacks, London.

Lewin, K., 1946, 'Action research and minority problems', in G.W. Lewin (ed.), Resolving social conflict, pp. 34-46, Harper and Row, London.

Lewin, K., 1947a, 'Frontiers in group dynamics', in D. Cartwright (ed.), Field theory in social science, pp. 5-41, Social Science Paperbacks, London.

Lewin, K., 1947b, 'Group decisions and social change', in T.M. Newcomb \& E.L. Hartley (eds.), Readings in social psychology, pp. 197-211, Henry Holt, New York.

Lippitt, R., Watson, J. \& Westley, B., 1958, Dynamics of planned change, Harcourt, Brace, New York.

MacCulloch, D., 2005, The reformation: A history, Penguin Books, London.

Makhanya, M., 2012, The actors have changes, but the plot stays the same, Leader.co.za, viewed 04 April 2012, from http://www.leader.co.za/article.aspx?s=1\&f=1\&a=3547

Oliver, E., 2013, 'Teaching open distance learning undergraduates in theology to become effective change agents', Verbum et Ecclesia 34(1), Art. \#845, 1-7. https:// doi.org/10.4102/ve.v34i1.845
Oyler, C., 2012, Actions speak louder than words: Community activism as curriculum, Routledge, New York.

Pijoos, l., 2016, '2 Kruger park rangers in court over rhino horns worth R2m', viewed 11 July 2016, from http://www.news24.com/SouthAfrica/News/2-kruger-parkrangers-in-court-over-rhino-horns-worth-r2m-20160620

Roelf, W., 2016, South African cabinet says to take measures to curb rising unemployment, viewed 13 May 2016, from http://af.reuters.com/article/ southAfricaNews/idAFJ8N17V0OI

Rogers, E.M., 1962, Diffusion of innovations, Free Press of Glencoe, New York.

Schaff, P. (ed.), 1885, Nicene and post-Nicene Fathers, Series 2. Vol. 1: Eusebius Pamphilius: Church History, Life of Constantine, Oration in Praise of Constantine, Christian Classics Ethereal Library, Grand Rapids, MI.

Schein, E.H., 1988, Organizational psychology, 3rd edn., Prentice Hall, London.

Scherer, F., 2013, 'Policy options for reducing road accidents in South Africa', in Political Analysis South Africa, viewed 28 January 2013, from http://www.politicalanalysis. co.za/2013/01/04/policy-options-for-reducing-road-accidents-in-south-africa/

Schmidt, A.J., 2004, How Christianity changed the world, Zondervan, Grand Rapids, MI. Statistics South Africa, 2004, Primary tables, Stats SA, Pretoria.

Sunshine, G.S., 2009, Why you think the way you do: The story of western world views from Rome to home, Zondervan, Grand Rapids, MI.

The Free Dictionary, Word meanings, viewed 16 November 2015, from www. thefreedictionary.com/

Themeshnews, 2016, Top 10 countries with the highest murder rate in the world 2016, viewed 21 March 2016, from http://www.themeshnews.com/top-10 countries-with-highest-murder-rate-in-the-world-2016/

Travis, C. \& Aronson, E., 2007, Mistakes were made - But not by me - Why we justify foolish beliefs, bad decisions and hurtful acts, Houghton Mifflin Harcourt, New York.

UNESCO, 1997, 'Declaration of Thessaloniki', in International Conference on Environment and Society: Education and Public Awareness for Sustainability,
UNESCO and the Government of Greece, viewed 06 March 2016, from http:// UNESCO and the Government of Greece, viewed
www.unesco.org/iau/sd/rtf/sd_dthessaloniki.rtf

Unisa, 2013, Community engagement and outreach policy, viewed 16 June 2016, from http://www unisa.ac.za/contents/faculties/ems/docs/Community $\% 20$ Engagement $\% 20$ and $\% 200$ utreach $\% 20$ Policy $\% 20-020$ rev $\% 20$ appr $\% 20$ Engagement \%20and\%200ut
Council\%20-\%2020.09.2013.pdf

United Nations Development Programme (UNDP), 2011, Human development reports, viewed 11 April 2012, from http://hdr.undp.org/en/statistics

United Nations Development Programme (UNDP), 2015, Development reports, viewed 13 May 2016, from http://hdr.undp.org/sites/default/files/2015_human development_report.pdf

United Nations Office on Drugs and Crime (UNODC), 2012, Homicide statistics 19952011, viewed 29 January 2013, from www.unodc.org

Viljoen, C., 2016, South Africa slips to third-largest economy on the continent, viewed 13 May 2016 from http://www.cnbcafrica.com/news/southern-africa/2016/05/11/ south-africa-slips-to-third-largest/

Warren, R., 2005, 'Rick Warren's second reformation', presented with Tony Campolo and Jimmy Carter at the 19th Congress of the Baptist World Alliance, Birmingham, 27-31 July, viewed 07 November 2011, http://www.lighthousetrailresearch.com/ rw2ndreformation.htm

Weiss, C.H., 1995, 'Nothing as practical as good theory: Exploring theory-based evaluation for comprehensive community initiatives for children and families', in evaluation for comprehensive community initiatives for children and families', in Concepts, methods, and contexts, pp. 65-92, Aspen Institute, Washington.

World Health Rankings, 2014, Road traffic accidents death rate per 100 000, viewed 16 June 2016, from http://www.worldlifeexpectancy.com/cause-of-death/roadtraffic-accidents/by-country/

Yale, 2016, Environmental performance index, viewed 13 May 2016, from https:// issuu.com/2016yaleepi/docs/epi2016 final

Yale \& Colombia Universities, 2012, Environmental performance index in Yale University, viewed 11 April 2012, from http://epi.yale.edu/epi2012/countryprofile 